\title{
Mandible condyle osteochondroma: clinical case report
}

\author{
Osteocondroma do côndilo da mandíbula: relato de caso clínico
}

Denis Pimenta e SOUZA ${ }^{1}$

José Luiz Cintra JUNQUEIRA²

Ricardo RAITZ²

\begin{abstract}
Osteochondroma is one of the most common benign bone tumours. However, it a rare in the mandibular condyle. Depending on the symptoms and duration of the osteochondroma, the management ranges from excision of the tumor alone to condylectomy along with tumor excision. This paper presents a case of Osteochondroma after surgical treatment affecting the mandible of a 39-year-old man and highlights the diagnosis, surgical procedures and 3-year follow-up period. At the clinical examination, the patient presented severe mandibular lateral deviation to the right, left side disocclusion with a slight oral opening limitation, dental abrasion compatible with bruxism and class III. After 3-year follow-up 3 years later revealed that the surgical management posed was successful for Osteochondroma and the patient is currently under regular review.
\end{abstract}

Indexing terms: Cone beam computed tomography. Diagnosis. Osteochondroma. Treatment.

\section{RESUMO}

Osteocondroma é um dos tumores ósseos mais comuns, mas raramente acomete o côndilo mandibular. Dependendo dos sintomas e duração do Osteocondroma o manejo da lesão pode variar desde a excisão do tumor até a realização da condilectomia com a remoção do tumor. O objetivo deste trabalho é relatar um caso clínico de Osteocondroma acometendo o côndilo da mandíbula em um paciente de 39 anos de idade, ressaltando as etapas para a realização do diagnóstico, procedimentos cirúrgicos e follow-up de 3 anos. Ao exame clínico observou-se severo desvio mandibular para o lado direito, desoclusão do lado esquerdo, abertura de boca reduzida, abrasão dentária compatível com bruxismo e classe III. Após a realização de tratamento cirúrgico e o período de acompanhamento de 3 anos foi possível observar a resolução do caso em imagens de tomografia computadorizada de feixe cônico. Conclusão: Pode-se concluir que a terapia proposta resultou em sucesso e o paciente continua em acompanhamento periódico.

Termos de indexação: Tomografia computadorizada de feixe cônico. Osteocondroma. Diagnóstico. Tratamento.

\section{INTRODUCTION}

Osteochondroma is one of the most common benign bone tumours. Although frequently found in the general skeleton, it is rarely seen to involve the facial bones $^{1-4}$. It usually occurs early in life affecting young adults between 10-30years of age but the craniofacial Osteochondroma are frequently seen in older women ${ }^{5}$.

The clinical presentation of Osteochondroma includes facial asymmetry, malocclusion, cross-bite on contra-lateral side and lateral open-bite on the affected side, deviation on opening, hypomobility, pain and clicking ${ }^{6}$. Pre-auricular swelling, TMJ pain, cliking sound and recurrent joint dislocation are also common manifestation of the tumour ${ }^{7}$. Differential diagnosis of slow-growing tumours in the mandibular condyle Osteochondroma include giant cell tumor, condylar hyperplasia, fibro-osseous lesion, vascular malformation, osteoma, chondroma, and osteochondroma-9.9. Pre operative computed tomography scans are (CT) scans is essential in the treatment planning of these tumours and depending on the symptoms and duration of the osteochondroma, the management ranges from excision of the tumor alone to condylectomy along with tumor excision ${ }^{1}$.

A recent paper ${ }^{10}$ reported that the treatment of osteochondroma remains controversial because some authors have proposed conservative resection with

\footnotetext{
${ }^{1}$ Hospital Paulistano, Serviço de Cirurgia e Traumatologia Buco-Maxilo-Facial. São Paulo, SP, Brasil.

${ }^{2}$ Faculdade São Leopoldo Mandic, Pós-Graduação em Odontologia. Rua José Rocha Junqueira, 13, 13045-755, Swift, Campinas, SP, Brasil. Correspondência para / Correspondence to: R RAITZ. E-mail: ricardoraitz@ig.com.br.
} 
preservation of most of the condyle by removing the tumour in multiple fragments. On the other hand, some authors proposed simultaneous condylar reconstruction and condylectomy. This paper presents a case of Osteochondroma after surgical treatment affecting the mandible of a 39-year-old man and highlights the diagnosis, surgical procedures and 3-year follow-up period.

\section{CASE REPORT}

A dark-skin, 39 years old patient, from the city of Osasco, State of São Paulo, Brazil, attended the dental clinic complaining of left otalgia, left temporomandibular joint burst (TMJ), muscle fatigue during chewing, occasional tinnitus, limited mandibular opening, scapular and occipital pain and no previous temporal headache. The patient reported good general health and no chronic use of medications, either. At the clinical examination, the patient presented the following symptoms: severe mandibular lateral deviation to the right, left side disocclusion with a slight oral opening limitation, dental abrasion compatible with bruxism and class III (Figure 1A and B).
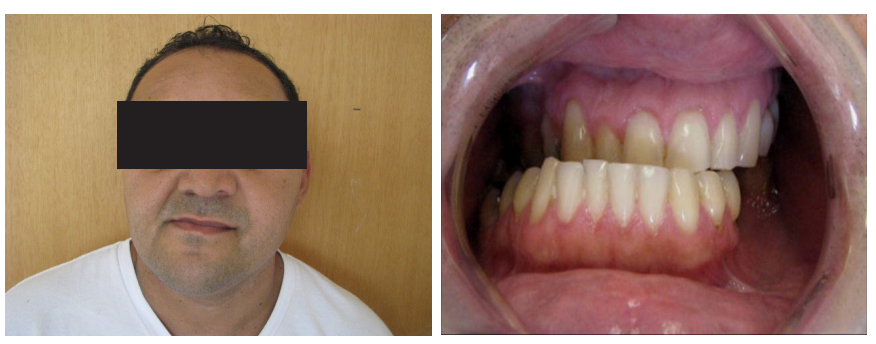

Figure 1. A and B - At the clinical examination, the patient presented severe mandibular lateral deviation to the right, left side disocclusion with a slight oral opening limitation, dental abrasion compatible with bruxism and class III.

At first, condylar hyperplasia on the left side was hypothesized and orthodontic documentation was requested during which severe malocclusion was confirmed and growth in the subcondylar region on the left side was clear. The tomographic examination revealed some masslike dysformed condylar growth, extending medially from the left subcondylar region from where it approached the anatomical condyle right into the temporal bone mandibular fossa (Figure 2). The patient was retrospectively evaluated concerning childhood trauma with mandibular impact, to which he initially denied but later recalled having had mild trauma when he was about 8 years old.
The bone scintigraphy examination showed active and proliferative condylar and subcondylar development and hyperstimulation was observed in the left condylar area, right knee and right shoulder.

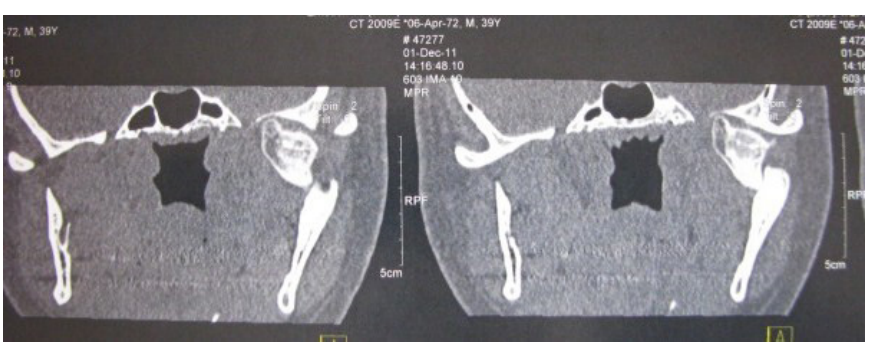

Figure 2. The tomographic examination revealed some mass-like dysformed condylar growth, extending medially from the left subcondylar region from where it approached the anatomical condyle right into the temporal bone mandibular fossa.

The preoperative exames were normal and the surgery was perfomed in a surgical center, under anesthesia, naso-tracheal intubation, since the patient's limited dental occlusion was important in the intraoperative period. A preauricular incision was performed with a small extension to the retromandibular area. Surgical divulsion was perfomed following the facial nerve path in order to access the marginal mandibular branch, which was anatomically normal. A narrow base bone projection with progressive increase towards the mandibular fossa with appearance of irregular and hardened mass, similar to a bone, was observed through a subcondylar medial procedure. Due to the difficulties of access, a piezo tip cut of the normal subcondylar area was performed, the TMJ was devulsed and the normal condyle completely extirpated. The tumor resection-osteotomy was performed and immersed in isotonic solution, lactated ringer type.

The tumor was immediately subjected to a hospital pathological examination and no malignancy was found. Replacement of the healthy condyle was planned, with adequate marginal medial ostectomy, with a small margin followed by regularization and constant lactated ringer solution irrigation. The rigid internal fixation with titanium plates and screws, system 2.0 (Figures 3 A, B and C) was then performed.

The postoperative period was expected to restore the patient's vertical and functional balance even though he was informed that it would function as a free graft after surgical manipulation and removal of the periosteum. Hemostasis was then performed, abundant irrigation with saline solution and suture with placement of local compressive dressing were done. The tumor was 
subjected to anatomopathological examination, aiming at final diagnosis confirmation (Figure 4). During the 48hour postoperative period the patient developed mild facial nerve neuro-apraxia, especially in the frontal and zygomatic branches, which were treated with low-power stimulating 40J / 808 laser therapy in 3 weekly sessions, for 6 weeks.

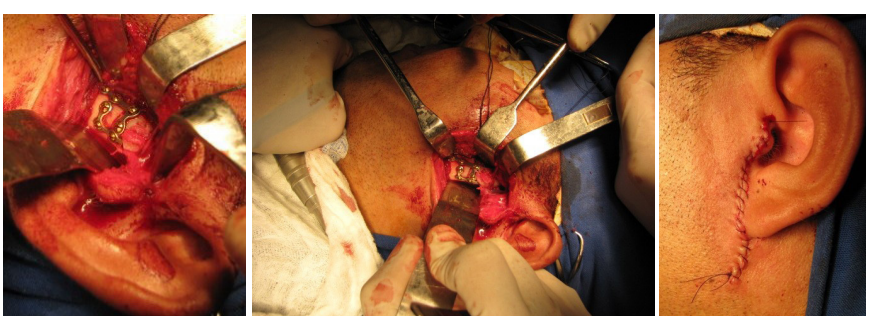

Figure 3. Surgical procedures: Replacement of the healthy condyle was planned, with adequate marginal medial ostectomy, with a small margin followed by regularization and constant lactated ringer solution irrigation. The rigid internal fixation with titanium plates and screws, system 2.0 was then performed.

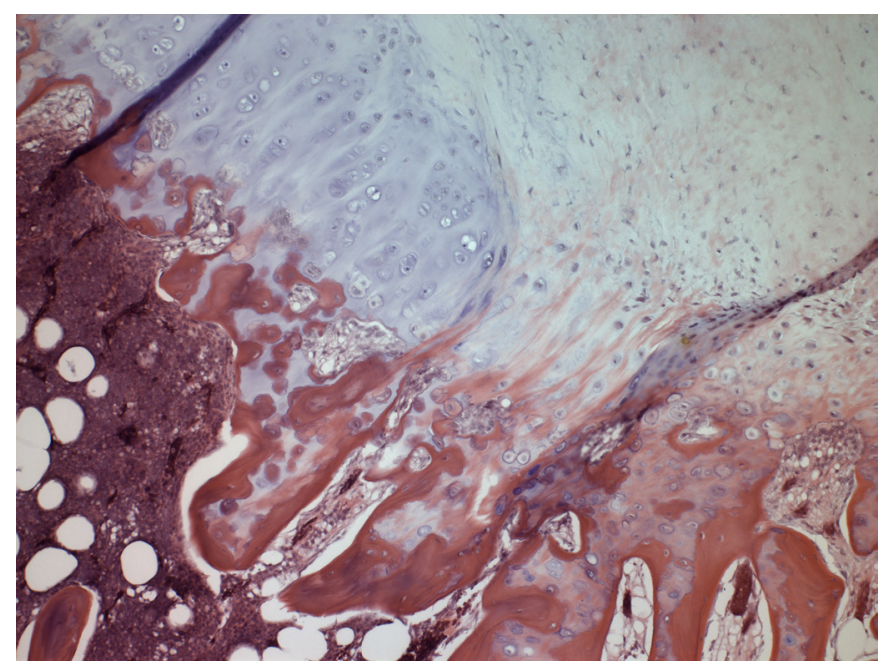

Figure 4. The histological findings revealed cancellous bones covered in some parts by cartilaginous cap.

A progressively released diet and local massage stimulation physiotherapy in the left masticatory musculature, heat and ice thermotherapy as well as isometric exercises were oriented. A citoneurin-type medication was prescribed twice a day for 30 days, aiming at neurological improvement. There was gradual improvement of neuro-apraxia and muscle function, with total regression of edema at 4 weeks. The dental occlusion was reestablished, presenting no laterognatia or masticatory difficulties as it had been reported by the patient at the beginning of the treatment.
The pathological anatomy revealed osteochondroma, confirming the benign prognosis of the lesion and corroborating the conservative treatment given to the case.

The clinical changes have resulted in patient's healthy control of function and aesthetic appearance, no facial-related disorders, restored functional occlusion and no pain complaints after a 3 year- follow-up (Figure $5 \mathrm{~A}$, $B$ and $C$ ).

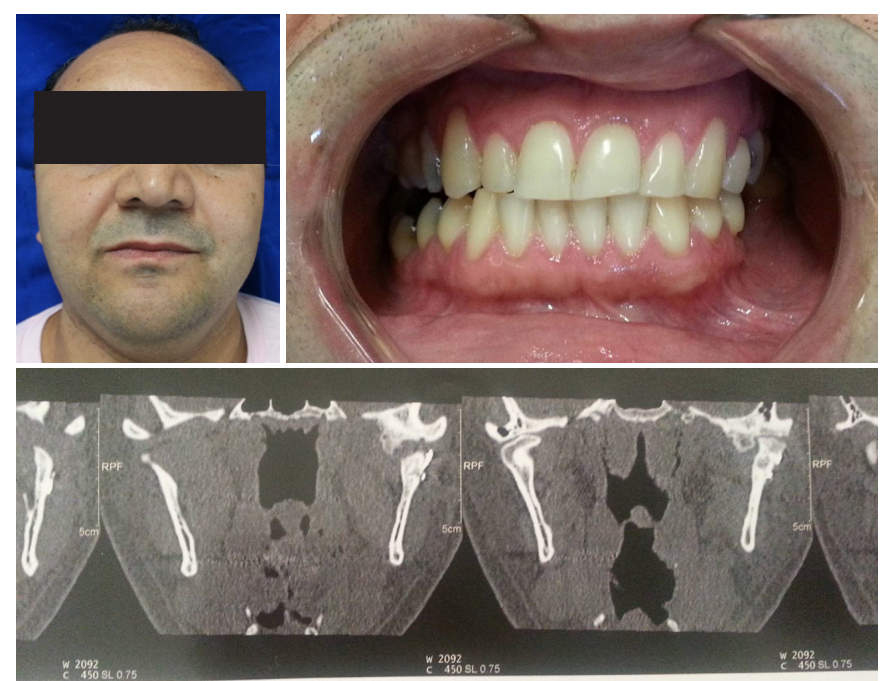

Figure 5. Extra (A), intraoral (B) and tomographic aspects (C) in a 3-year follow-up period. The clinical changes have resulted in patient's healthy control of function and aesthetic appearance, no facial-related disorders and restored functional occlusion.

\section{DISCUSSION}

This report presents a case of osteochondroma in a 39-year-old male patient involving the left condyle which was accompanied by the main symptoms: otalgia, TMJ noise of the left side, mastication difficult and limited mouth opening. The patient presented the patient presented severe mandibular lateral deviation to the right, left side disocclusion with a slight oral opening limitation, dental abrasion compatible with bruxism and class III.

A previous study reported that five patients with unilateral osteochondroma of the madibular condyle had the main complaint of pain in the temporomandibular joint and no patients were so disturbed by facial asymmetry. The sites of predilection were the coronoid process and the mandibular condyle ${ }^{3}$.

The etiology of osteochondroma is unclear ${ }^{12}$. For the present case report, the history of mild trauma when he was about 8 years old might be the possible cause of 
osteochondroma.

According to Andrade et al. ${ }^{1}$ much confusion seems to exist in the literature in differentiating osteochondroma from chondromas as well condylar hyperplasias. Clinicopathological and radiological differentiation should be carried out between the two lesions. In addition, it is important to highlight that the treatment plan differs for both these conditions ${ }^{1}$. Radiographic appearance of osteochondroma of the mandibular condyle can be pathognomonic, appearing as an irregularly shaped, mixed density and expansile lesion ${ }^{4}$. Early diagnosis is essential in order to provide adequate treatment, which may affect the patient's quality of life ${ }^{13}$.

In the present case lesion was surgically removed. According to the literature, the surgical treatment for osteochondroma of the mandibular condyle is condylectomia with or without simultaneous reconstruction of the condyle ${ }^{10}$. Several reconstructive options are available in the literature. Zhou et al. ${ }^{10}$ followed up 10 patients with osteochondroma who had the condyle resected or reconstructed. Three patients were treated with a free graft and seven with a pedicled graft. The authors concluded that both free grafts and pedicled graft seem to be alternative and promising approaches to condylar reconstruction in the treatment of osteochondroma. However, the pedicled graft results in less facial asymmetry,

\section{REFERENCES}

1. AndradeNN, GndhewarTM, KapoorP, ThomasR. Osteochondroma of the mandibular condyle - Report of and atypical case and the importance of computed tomography. J Oral Biol Craniofac Res. 2014;4(3):208-13. doi: 10.1016/j.jobcr.2014.12.001

2. Dominguez MF, Castillo JL, Guerra MM, Sanchez RS, La Plata MM. Condylar osteochondroma treated with total condylectomy and preservation of the articular disc: a case report. Craniomaxillofac Trauma Reconstr. 2015;8(2):136-40. doi: 10.1055/s-00341393727

3. Jain M, Singhal S, Goyal M, Sharma B. Osteochondroma of maxilla posterior region: a unique case. J Clin Diagn Res. 2015;9(4):ZD145. doi: 10.7860/JCDR/2015/12478.5804

4. $\mathrm{M} \mathrm{H}$, Manjunatha BS, Kumar AN, Alavi YA. Osteochondroma (OC) of the condyle of left mandible: a rare case. J Clin Diagn Res. 2015;9(2):ZD15-6. doi: 10.7860/JCDR/2015/11451.5598

5. Utumi ER, Pedron IG, Perrela A, Zambon CE, Cecchetti MM, Cavalcanti MG. Osteochondroma of the temporomandibular joint: a case report. Braz Dent J. $2010 ; 21(3)$ :253-8.

6. Wolford LM, Mehra P, Franco P. Use of conservative condylectomy for treatment of osteochondroma of the mandibular condyle. J Oral Maxillofac Surg. 2002;60:262-e68. doi: 10.1053/ joms.2002.30570 less bone resorption, and better long-term clinical effects than the free graft. Condylectomy and condylar reconstruction, with simultaneous correction of the secondary dentofacial deformities adopting orthodontic procedures, might be a better alternative in order to manage osteochondroma accompanied by dentofacial deformities. Moreover, orthodontic treatment should be used for better improvement in facial esthetics and occlusion $^{14}$.

It is important to highlight that surgical resection of osteochondroma can lead to complications such as: neuropraxia, fracture and arterial laceration ${ }^{9,11}$. Follow-up was carried out in our case as the patient did not present any complication. Recurrence rate of the lesion after resection is considered extremely rare ${ }^{9}$. However, due to these chances of recurrence the patient is currently under regular review and there was no evidence of recurrence.

\section{Collaborators}

DP SOUZA assisted the patient in the case here reported. JLC JUNQUEIRA and R RAITZ made substantial contributions to all stages of this paper. All authors approved the final version and its submission to this journal.

7. Meng Q, Chen S, Long X, Cheng Y, Deng M, Cai H. The clinical and radiographic characteristics of condilar osteochondroma. Oral Surg Oral Med Oral Pathol Oral Radiol. 2012;114:e-66-74. doi: 10.1016/j.0000.2012.01.016

8. Vezeau PJ, Fridrich KL, Vincent SD. Osteochondroma of the mandibular condyle: literature review and report of two atypical cases. J Oral Maxillofac Surg. 1995;53:640.

9. Kamble V, Rawat J, Kulkarni A, Pajnigara N, Dhok A. Osteochondroma of bilateral mandibular condyle with review of literature. J Clin Diagn Res. 2016;10(8):TD01-02. doi: 10.7860/ JCDR/2016/19877.8361

10. Zhou H, Liao $\mathrm{C}, \mathrm{Hu}$ J, Fei W. Comparison of the clinical effects of treatment of osteochondroma by two types of vertical ramus osteotomy. Br J Oral Maxillofac Surg. 2017 Feb 26. pii: S02664356(16)30296-0. doi: 10.1016/j.bjoms.2016.09.023

11. Holmlund AB, Gynther GW, Reinholt FP. Surgical treatment of osteochondroma of the mandibular condyle in the adult. A 5-year follow-up. Int J Oral Maxillofac Surg. 2004;33(6):549-53. doi: 10.1016/j.ijom.2004.01.006

12. Yang $\mathrm{XH}$, Zhang $\mathrm{P}, \mathrm{Xu} J \mathrm{H}, \mathrm{Hu}$ YJ. An osteochondroma of the mandibular condyle. J Craniofac Surg. 2015 Mar;26(2):567-9. doi: 10.4103/0976-9668.116969

13. Tantanapornkul W, Dhanuthai K, Sinpitaksakul P, Itthichaisri C, Kamolratanakul P, Changsirivatanathamrong V. Dentofacial 
deformity caused by bulky osteochondroma: report of an unusual case and the importance of cone beam computed tomography. Open Dent J. 2017 Apr 28;11:237-241. doi: $10.2174 / 1874210601711010237$

14. Li H, Hu J, Luo E, Zhu S, Li J. Treatment of osteochondroma in the mandibular condyle and secondary dentofacial deformities using surgery combined with orthodontics in adults. J Oral
Maxillofac Surg. 2014 Nov;72(11):2295-317. doi: 10.1016/j. joms.2014.03.021

Received on: $27 / 4 / 2017$ Final version resubmitted on: 11/7/2017

Approved on: 28/8/2017 